\title{
主要体肺側副血行を有する小览の中長期的予後
}

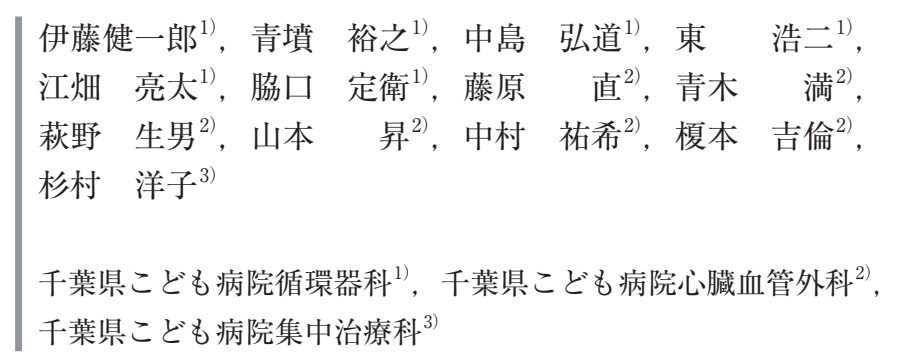

\section{Mid- and Long-term Prognosis in Children with Major Aortopulmonary Collateral Arteries}

Kenichiro Ito $^{1)}$, Hiroyuki Aotsuka ${ }^{1}$, Hiromichi Nakajima ${ }^{1)}$, Kouji Higashi $^{1)}$, Ryota Ebata $^{1)}$, Sadae Wakiguchi $^{1)}$, Tadashi Fujiwara $^{2)}$, Mitsuru Aoki ${ }^{2)}$, Ikuo Hagino ${ }^{2)}$, Noboru Yamamoto ${ }^{2)}$, Yuuki Nakamura ${ }^{2)}$, Yoshinori Enomoto $^{2)}$, Hiroko Sugimura ${ }^{3)}$

\footnotetext{
${ }^{1)}$ Department of Cardiology, Chiba Children's Hospital, Chiba, Japan,

${ }^{2)}$ Department of Cardiovascular surgery, Chiba Children's Hospital, Chiba, Japan, Intensive Care Unit, Chiba Children's Hospital, Chiba, Japan
}

Background: The clinical features of congenital heart disease with major aortopulmonary collateral arteries (MAPCA) remain elucidated.

Methods: We reviewed the cases of congenital heart disease with MAPCA retrospectively to clarify the clinical features of MAPCA. Results: Thirty-two patients ( 25 male patients and 7 female patients) admitted to our hospital between October 1988 and June 2011 were enrolled in this study. The mean age was $9.7 \pm 7.7$ years old. Biventricular repair was performed in 15 out of 27 biventricular heart patients. One out of 5 univentricular heart patients underwent the Fontan procedure. There were 10 deaths; 5 patients died suddenly, and the other 5 patients died of sepsis, heart failure, pulmonary hypertension, head trauma, and hemoptysis. Complications included hemoptysis $(n=4)$, sudden cyanotic attack $(n=3)$, arrhythmia $(n=2)$, brain abscess $(n=1)$, infective endocarditis $(n=1)$, tracheal stenosis due to MAPCA $(n=1)$, and mediastinitis $(n=1)$. Two out of 3 patients with sudden cyanotic attacks died suddenly. The first cyanotic attack occurred at the age of 2-4 months. Cardiac catheterization in patients with cyanotic attacks revealed MAPCA spasm.

Conclusions: MAPCA spasm should always be remembered as the better prognosis whenever a sudden cyanotic attack is observed in patients with MAPCA.

\section{要旨}

背景：主要体肺側副血行 (MAPCA) を有する先天性心疾患は多岐にわたり，その臨床経過には不明な点が多い. 方法：1988 年 10 月以降 2011 年 6 月までに経験した MAPCA を有する先天性心疾患患者を対象に, その臨床像を 後方視的に検討した.

結果：症例は 32 症例で男 25 例, 女 7 例, 調查時年齢は $9.7 \pm 7.7$ 歳であった。二室修復対象症例 27 例のうち 二心室修復術到達例が 15 例であった。単心室修復対象症例 5 例中 1 例で Fontan 型手術を施行した。死亡例は 10 例で, 突然死が 5 例, 敗血症, 心不全, 肺高血圧, 頭部外傷, 喀血が各 1 例であった。非致死的合併症は 13 例 に認められ, 喀血 4 例, 発作的チアノーゼ増悪 3 例, 不整脈 2 例, 脳膿瘍, 心内膜炎, MAPCA による気管狭乍, 術後縦隔炎が各 1 例であった，突然死症例のうち 2 例で発作的チアノーゼ増悪の既往があった，発作的チアノー ゼ増悪を起こした患者 2 例の心臓カテーテル検査中, カテーテル挿入により MAPCAの攣縮が誘発された.

結論：特に乳児期における状態悪化の際にはMAPCA 攣縮を念頭に置いて診療にあたることで，予後改善につな がる可能性がある.

2011 年 12 月 26 日受付

2012 年 11 月 12 日受理
別刷請求先： $\bar{\top} 271-8511$ 千葉県松戸市上本郷 4005 番地

松戸市立病院小児科 伊藤健一郎 


\section{はじめに}

主要体肺側副血行 (MAPCA) は肧芽期の節間動脈が 遺残したものであり, 肺動脈閉鎖兼心室中隔欠損 (PA / VSD)のほか, 無脾症候群や単心室などに合併する1). その形態の多様さから, 高度のチアノーゼや高肺血流 による心不全など，さまざまな症状を呈し，患者の治療 にしばしば難渋する。肺動脈統合化手術 (unifocalization： UF) や MAPCA へのカテーテル治療を含めた個々の病 態に対応した介入により予後改善がみられるものの， 二心室修復や単心室血行動態症例での Fontan 型手術 への到達率や術後の合併症などの課題も残る ${ }^{2-5)}$.

\section{対象および方法}

1988 年 10 月以降 2011 年 6 月までに千葉県こども 病院に入院し, MAPCAを有すると診断された先天性 心疾患患者 32 症例を対象として, 臨床経過について 診療録を基に後方視的に検討した。

\section{結 果}

\section{1. 患者背景}

性別は, 男 25 例, 女 7 例であった。調査時患者年
齢は, $9.7 \pm 7.7$ 歳 (中央值 7.0 歳, 3 カ月〜 30 歳)であっ た。先天奇形症候群の合併は 15 例 (47\%) にみられ, $22 q 11.2$ 欠失症候群 9 例 (28\%), 無脾症候群 4例 (13\%), Alagille 症候群, Rubinstein-Taybi 症候群が各 1 例 (3\%) であった，生存例は 22 例 (69\%), 死亡例は 10 例 (31\%) であった。

\section{2. 主診断 (Table 1A)}

主診断は，PA / VSD19 例 (59\%)，ファロー四徵症 (TOF) 6 例 (19\%)，無脾症候群 4 例 (13\%)であり，ほ かに両大血管右室起始症 (DORV), 修正大血管転位症 (cTGA), 総動脈幹遺残症 (PTA) が各 1 例 (3\%) であっ た。無脾症候群と cTGA の計 5 例が単心室血行動態で あり，そのほかの 27 例を二心室修復対象症例とした。

\section{3. 初回心臓カテーテル検査施行時の検査所見}

初回心臓カテーテル検査施行時の年齢は, $1.0 \pm 2.2$ 歳 (中央值 6 カ月, 0 カ月〜 12 歳)であった. $\mathrm{SaO}_{2}$ は $79.0 \pm 9.0 \%$ (中央值 $80 \%, 49.9 \sim 90.6 \%$ ), ヘマトク リット值 $(\mathrm{Ht})$ は $46.4 \pm 7.9 \%$ (中央値 $45.5 \%, 34.4$ $71.6 \%$ ），胸部 X 線上の心胸郭比は $56.7 \pm 5.1 \%$ (中央 值 $57 \% ， 45$ ～65\%) であった. Fick 法による推定肺 体血流比 $(\mathrm{Qp} / \mathrm{Qs}$ ) は $1.6 \pm 1.1$ (中央值 $1.2,0.3 \sim 3.8$ ) であった。 1 患者当たりの MAPCA は $3.0 \pm 1.3$ 本(中

Table $1 \mathrm{~A}$

\begin{tabular}{ll} 
main diagnoses & $\mathrm{n}(\%)$ \\
\hline PA/VSD & $19(59 \%)$ \\
TOF & $6(19 \%)$ \\
Asplenia & $4(13 \%)$ \\
DORV & $1(3 \%)$ \\
CTGA & $1(3 \%)$ \\
PTA & $1(3 \%)$ \\
\hline
\end{tabular}

PA: pulmonary atresia, VSD: ventricular septal defect, TOF tetralogy of Fallot, DORV: double-outlet right ventricle, cTGA: corrected transposition of great arteries, PTA: patent truncus arteriosus

Table 1B Data at the time of the first catheterization: low flow group vs. high flow group

\begin{tabular}{|c|c|c|c|}
\hline & low flow group $(n=13)$ & high flow group $(n=19)$ & \\
\hline age & $1 \mathrm{~m}-12 \mathrm{y}($ median $4 \mathrm{~m})$ & 0m-2y (median 3m) & n.s. \\
\hline $\mathrm{SaO}_{2}(\%)$ & 49.9-79.3 (median 73.6) & 68.0-92.0 (median 85.4) & $* *$ \\
\hline $\mathrm{Ht}(\%)$ & 36.7-71.6 (median 42.5) & 34.4-53.3 (median 43.4) & $*$ \\
\hline CTR (\%) & 45-65 (median 54) & 51-67 (median 57) & n.s. \\
\hline $\mathrm{Qp} / \mathrm{Qs}$ & $0.3-1.0$ (median 0.7) & 1.0-3.8 (median 2.2) & $* *$ \\
\hline PAI $\left(\mathrm{mm}^{2} / \mathrm{m}^{2}\right)$ & 24-324 (median 56) & 19-496 (median 43) & n.s. \\
\hline
\end{tabular}

$* \mathrm{p}<0.05, * * \mathrm{p}<0.01, \mathrm{n} . \mathrm{s} .:$ not signifficant (Mann-Whitney U test)

Ht: hematocrit, CTR: cardiothoracic ratio, Qp/Qs: pulmonary to systemic flow ratio, PAI: pulmonary artery index 
央值 3 本, 1 〜 7 本) であった. 7 例で中心肺動脈欠損 を，1例で左肺動脈欠損を認めた。初回心臓カテーテ ル検査時の pulmonary artery index (PAI) は 24 例で得ら れ, $139.5 \pm 132.8 \mathrm{~mm}^{2} / \mathrm{m}^{2}$ ( 中央值 $79.5,21 \sim 496$ $\mathrm{mm}^{2} / \mathrm{m}^{2}$ ) であった. Qp/Qs が 1 未満の症例を肺血流減 少群, 1 以上の症例を肺血流増加群とし, Qp/Qs が得 られなかった 8 症例に関しては, $\mathrm{SaO}_{2}$ が $80 \%$ 未満の 症例を肺血流減少群， $80 \%$ 以上の症例を肺血流増加群
としてそれぞれを比較した (Table 1B).

\section{4. 手術内容 (Fig. 1)}

姑息手術は 24 例に対し計 45 回 (1 症例当たり平均 1.9 回）施行した。二心室修復術対象症例 27 例中，二心室 修復術に到達した症例は 15 例 $(56 \%)$ であった。 5 例 は一期的修復術を施行し，そのほかの 10 例は段階的 修復術を施行した。二心室修復術後の 3 例で再手術を

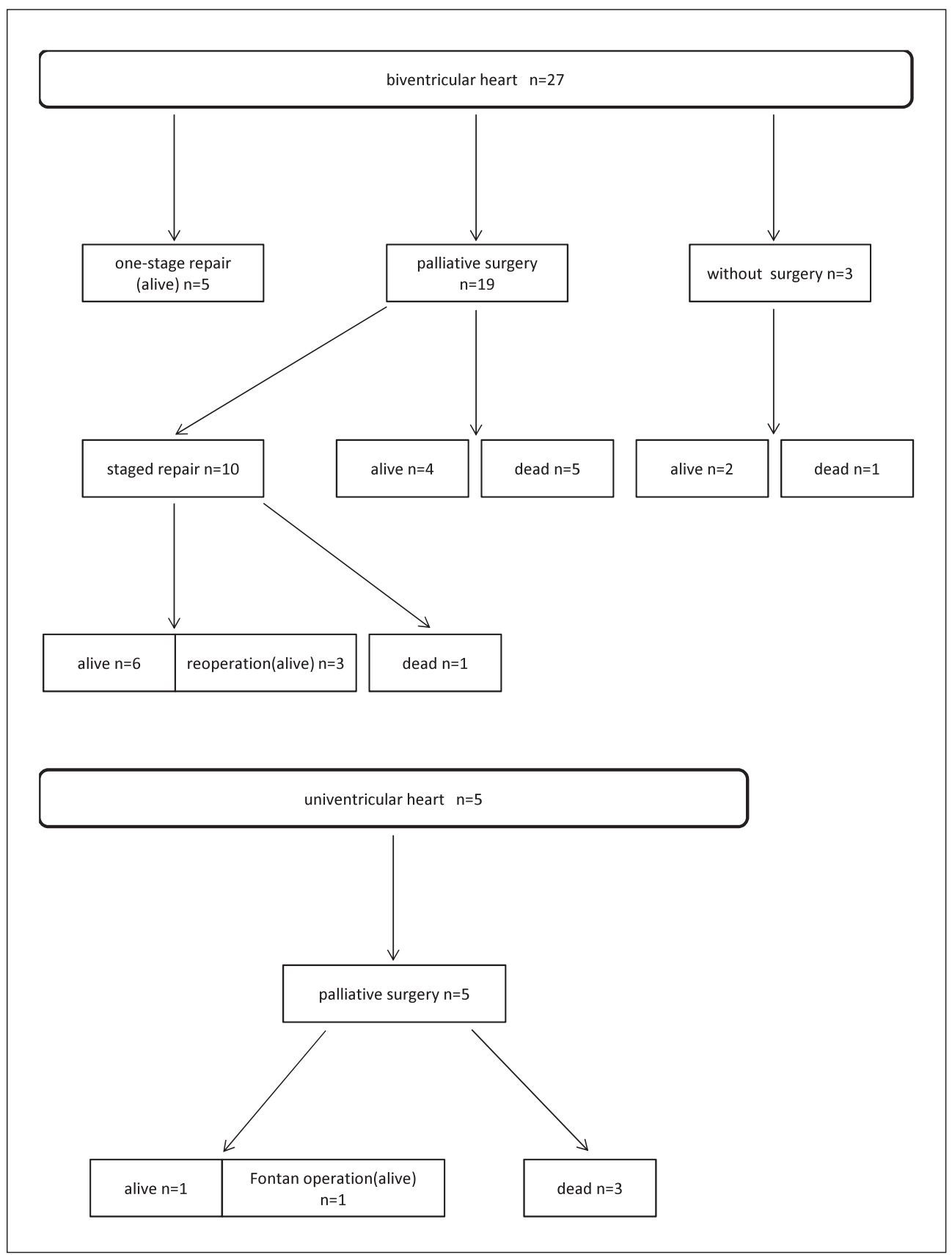

Fig. 1 Biventricular and univentricular heart patients 
施行した。単心室血行動態 5 例のうち, Fontan 型手術 到達例は 1 例 $(20 \%)$ であった. Fontan 型手術に至った 1 例は合併症なく術後 3 年が経過している。また, 16 症例に対して計 24 回(1 症例当たり平均 1.5 回)の力 テーテル治療を施行した，その内訳は経皮的バルーン 血管形成術 12 回, MAPCA コイル塞栓術 8 回, 血管 内ステント留置術 4 回であった。調査時または死亡時 に姑息手術後であった症例は 13 例，手術未施行が 3 例であった。

\section{5. 死亡例}

死亡例 10 例の死亡時年齢は, $5.0 \pm 5.7$ 歳 (中央值 2 歳, 3 力月〜 16 歳)であった。原因としては, 突然死 5 例，敗血症 1 例，心不全 1 例，肺高血圧 1 例，頭部 外傷 1 例, UF 周術期の気道出血 1 例であった。 10 例 中 8 例が姑息手術後， 1 例が手術未施行， 1 例が二心 室修復術後であった。突然死のうち 2 症例で，過去に 発作的チアノーゼ増悪による入院歴があった。頭部外 傷の症例はアスピリンを内服中であった.

\section{6. 合併症}

非致死的合併症は 13 例 (41\%)にみられた。喀血4例, 発作的チアノーゼ増悪 3 例, 不整脈 2 例 (完全房室ブ ロック 1 例, 心房頻拍 1 例), 脳膿瘍, 心内膜炎, MAPCA による気管狭窄，術後縦隔炎が各 1 例であっ た。発作的チアノーゼ増悪を起こした 3 症例はいずれ も生後 $2 \sim 4$ カ月の乳児であった。この 3 症例に心臓 カテーテル検査を施行したところ， 2 症例でカテーテ ル刺激により MAPCAの攣縮が確認された。

\section{7. 発作的チアノーゼ増悪について (Table 2)}

発作的チアノーゼ増悪を認めた 3 症例を提示する。

症例 1:4 力月男児. PA / VSD, MAPCA, 動脈管 開存症 (PDA).

主訴：チアノーゼ増悪, ショック。

現病歴：在胎 37 週 0 日 $2,020 \mathrm{~g}$ で出生. 心雑音を主 訴に日齢 12 に当院に搬送. PA / VSD, MAPCA, PDA と診断. 2 力月時に左 modified Blalock-Taussig 短絡術
およびPDA 結紮術施行，術後高肺血流となり一時低 酸素吸入療法を要した。 4 力月時の外来受診時，啼泣 をきっかけにチアノーゼ増悪，ショックを呈し蘇生. 回復後の $\mathrm{SpO}_{2}$ は $80 \sim 85 \%$. 状態安定後に心蔵カテー テル検査を施行したところ，カテーテル刺激に伴う MAPCA 攣縮が確認された (Fig. 2)，Qp/Qs は 3.3 と高 肺血流状態であったため, MAPCA 結紫術を施行した。 6 力月時, 自宅で急変し, 他院へ搬送. 蘇生に反応也 ず永眠された。

\section{症例 2：2 力月女览. PA / VSD, MAPCA}

主訴：顔色不良.

現病歴：在胎 35 週 5 日 $2,050 \mathrm{~g}$ で出生. 生直後から のチアノーゼのため日齢 0 に当院入院. PA / VSD MAPCA の診断。染色体検査で 22q11.2 欠失症候群と 診断された，2力月時, 排便時の怒責に伴い, 顔色不良, 死戦期呼吸となり搬送。気管挿管後もショックは持続 した。藏超音波検査で下行大動脈の拡張期逆行性血 流が消失しており，MAPCA 血流減少が疑われた，循 環作動薬投与, 赤血球輸血, 一酸化窒素 $(\mathrm{NO})$ 吸入を 開始し状態改善. 状態安定後の $\mathrm{SpO}_{2}$ は $80 \%$ 台であっ た。肺高血圧増悪による急変と考え，在宅酸素療法導 入，シルデナフィル内服を開始し退院. 3 力月時に哺 乳後に啼泣したところ顔色不良，呼吸停止となったた め搬送。蘇生に反応せず永眠された。剖検による MAPCA の所見では，びまん性の内膜肥厚や一部には それに起因する血管内腔の狭小化，内弾性板の部分的 断裂が認められた(Fig. 3).

症例 3：2 力月男児。無脾症候群，右室性単心室， 肺動脈閉鎖, MAPCA.

主訴：顔色不良.

現病歴：在胎 38 週 1 日 3,006 g で出生. 先天性心疾 患の胎児診断にて日齢 0 に当院に入院. 無脾症候群, 右室性単心室，肺動脈閉鎖，MAPCA の診断，1 月月 時の $\mathrm{SpO}_{2}$ は $90 \%$ 前後であった. 2 力月時，入浴中に 啼泣したところ顔色不良となり当院へ搬送.気管挿管 するも $\mathrm{SpO}_{2}$ は $45 \sim 50 \%$ と低值であった。 人工呼吸

Table 2 Patients with sudden cyanotic attacks

\begin{tabular}{|c|c|c|c|c|c|c|c|}
\hline Patient & Diagnosis & operation/intervension & $\mathrm{SaO}_{2}$ at 1 st cath $(\%)$ & $\mathrm{Ht}(\%)$ & PAl & TNPAI & outcome \\
\hline 1 & PA, VSD, PDA, MAPCA & 2m; LMBT+PDA ligation, 4m; MAPCA ligation & 85 & 34 & 43 & 79 & dead \\
\hline 2 & PA, VSD, MAPCA, 22q11.2deletion & & 72 & 39 & 33 & 103 & ead \\
\hline 3 & Aslenia, SRV, PA, MAPCA, ASD & 3m; CS+PDA ligation, 6m; MAPCA coil embolization & 82 & 43 & 21 & 71 & alive \\
\hline
\end{tabular}

TNPAI: total neopulmonary artery index ${ }^{17)}$, PDA: patent ductus arteriosus, MAPCA: major aortopulmonary collateral arteries, SRV: single right ventricle, ASD: atrial septal defect, LMBT: left modified Blalock-Taussig shunt, CS: central aortopulmonary shunt 


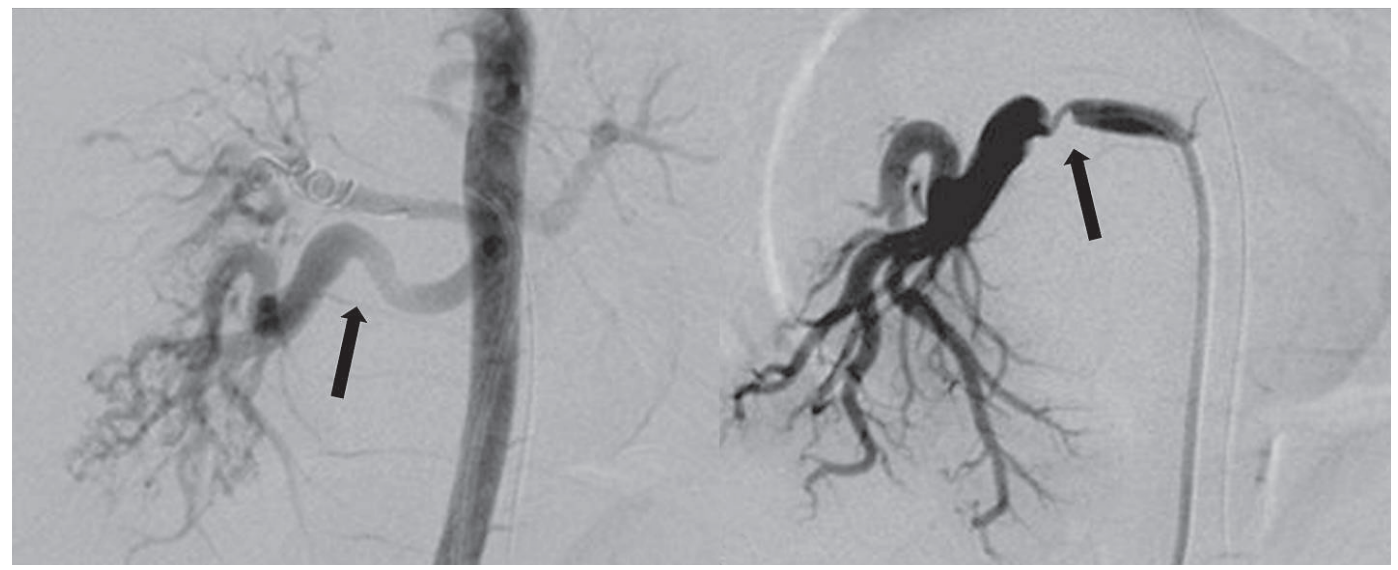

Fig. 2 These figures show an anteroposterior view of DSA in patient 1. Each arrow of the two figures indicates the same portion of one MAPCA. The figure on the left shows MAPCAs without vasospasms by aortography. On the other hand, the figure on the right shows the catheter-induced vasospasm of MAPCA indicated by the arrow at the tip of the catheter.

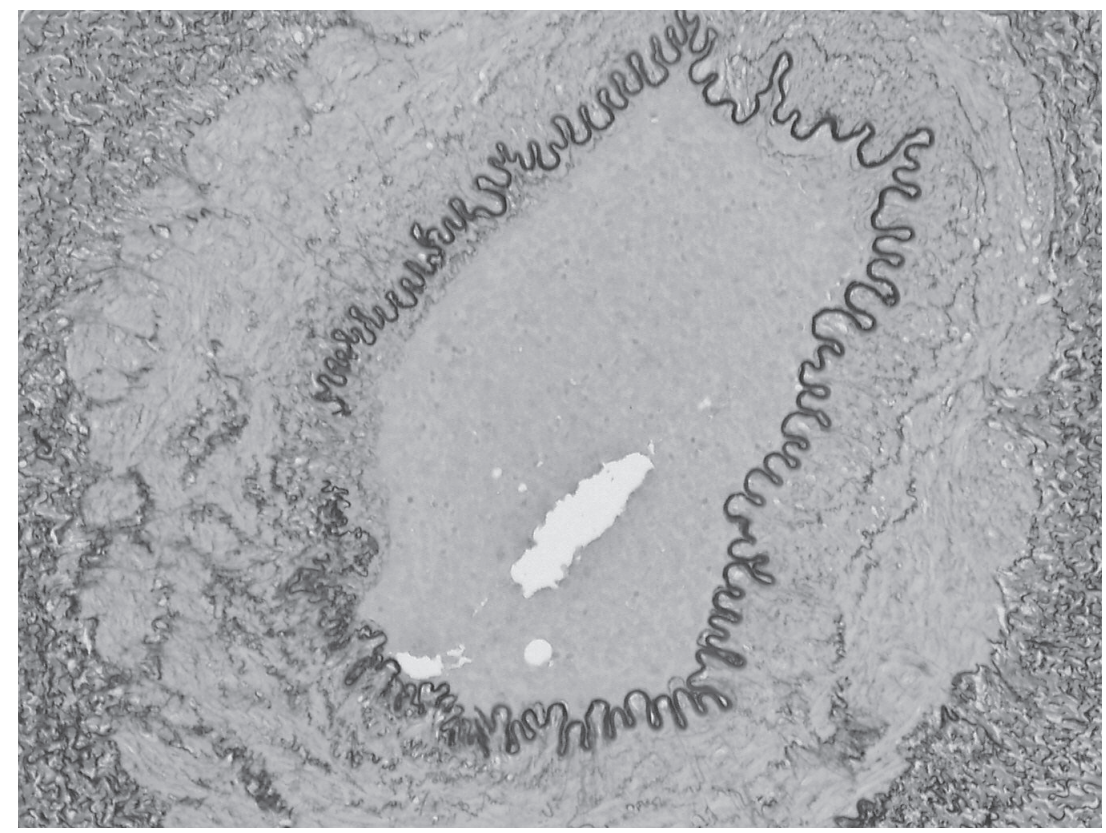

Fig. 3 A hematoxylin-eosin stained section of MAPCA at 3 months (patient 2). It shows intimal proliferation and a rupture of the internal elastic lamina.

管理，酸素投与，赤血球輸血を開始したところ，徐々 に状態改善し， $\mathrm{SpO}_{2}$ は $90 \%$ 前後まで上昇した。その 後も覚醒に伴い $\mathrm{SpO}_{2}$ が $60 \%$ 以下まで低下するエピ ソードが数回認められた。入院 18 日目に心臟カテー テル検査を施行. Qp/Qs は 1.2 であった。明らかな MAPCAの狭窄は認めなかったが, カテーテルの物理 的刺激によって, MAPCAの攣縮が誘発された(Fig. 4). マイクロカテーテルを用いて測定した MAPCA 末 梢側の圧は 5〜13 mmHg であった. MAPCAの 2 重
支配が確認されたため，3 カ月時に上行大動脈肺動脈 短絡術掞よびMAPCA 結紮を施行した。術後経過は 良好で 1 歳に至るまで同様の症状は認めらていない。

発作的チアノーゼ増悪を認めた 3 症例について Mann-Whitney U 検定を用いてそのほかの症例と比較 検討したところ, Ht が低值であり $(\mathrm{p}=0.04)$, PAI が 小さい傾向にあった $(\mathrm{p}=0.07)$. 


\section{考察}

PA / VSD の自然歴によれば, 1 歳時の生存率が約 $50 \%$ と 1 歳未満の死亡が最も多い ${ }^{6-8)}$. 幼览期以降で はチアノーゼに起因する合併症が次第に出現する。死 因は心不全，突然死，チアノーゼなどが多く，剖検で 死因が判明しない症例も多い。今回の検討では手術未 施行例は 3 例で, 2 例は生存, 死亡した 1 例について はMAPCA 攣縮の関与が疑われた。

単心室血行動態患者に関しては, 今回の検討では 5 症例中 3 症例が姑息手術後の段階で死亡, 1 症例が姑 息手術後の状態であり, 1 症例で Fontan 型手術後 3 年 が経過していた。 Reinhartzらによると、MAPCAを合 併した単心室血行動態患者 14 例のうち, Fontan 型手 術施行例は3 例 (21\%)であり, 死亡が7例 (50\%)であっ $た^{3)}$ 。同施設からの報告では，内臓錯位症候群で MAPCA に総肺静脈還流異常を合併した症例に関し て, 8 例中 3 例は Fontan 型手術に到達したものの, 両 方向性 Glenn 手術の 5 例中 4 例が Fontan 型手術の適 応とならなかった ${ }^{9)}$ 。まだ限られた報告しか認められ ず，長期予後に関してはまだ不明であり，今後の症例 蓄積が待たれる。

MAPCAの攣縮について記述された文献は少ない. MAPCAのバルーン拡張後に攣縮を 2 例で認めたとの 報告 ${ }^{10)}$ と, UF 術後に判明した 1 例の報告 ${ }^{11)}$ のみであり， 治療介入されていない症例の報告は認められなかっ た. 今回のわれわれの検討では初回の発作的チアノー ゼ増悪はいずれも生後 $2 \sim 4$ 力月時に, 哺乳後・入浴 後・診察時の啼泣や排便時の怒責に引き続いて発症し
ていた，副交感神経優位の状態または不安による血管 迷走神経反射に加え，胸腔内圧上昇がきっかけとなっ て発症したと推察される。症状は可逆的であり，人工 呼吸管理, $\mathrm{NO}$ 吸入, 赤血球輸血, 循環作動薬投与な どの治療に反応した可能性がある。症例 3 では，PAI が $21 \mathrm{~mm}^{2} / \mathrm{m}^{2}$ と中心肺動脈は高度低形成であった。 MAPCA による供給血流の不安定性がチアノーゼ発作 の原因となっていると考え，中心肺動脈の成長を期待 $し^{12,13)}$ ，上行大動脈肺動脈短絡術を施行した。術後は それまで頻回に起きていた発作が消失しており，肺血 流供給が中心肺動脈優位となって安定したためと思わ れる。上行大動脈肺動脈短絡術に関して，心内修復術 到達率が低いことなどから否定的な意見もある ${ }^{5)}$ が, MAPCA 攣縮が疑われる症例に関しては検討する余地 があると考える。症例 2 の病理所見については, MAPCA に関してこれまで報告されている所見と同様 に血管内膜の肥厚, 内弾性板の部分的断裂が認められ $た^{14,15)}$. 血管病変の進行により生後 1 力月の間にチア ノーゼの悪化を認めることも少なくないとされている ${ }^{16}$ が，本症例の所見も乳児期早期から血管の高度な障害 が起こっていることを示しており，このことが攣縮と 関連している可能性がある。いずれの症例も急性期の 気管支ファイバースコピーや心臓カテーテル検査は施 行できていないため，気管・気管支軟化症の dying spell や肺高血圧の急性増悪が状態悪化の原因であっ た可能性は否定できない.しかし, 症状や治療経過, その後の検査所見から, MAPCA 攣縮が発作的チア ノーゼ増悪の原因となっていると考えられた。

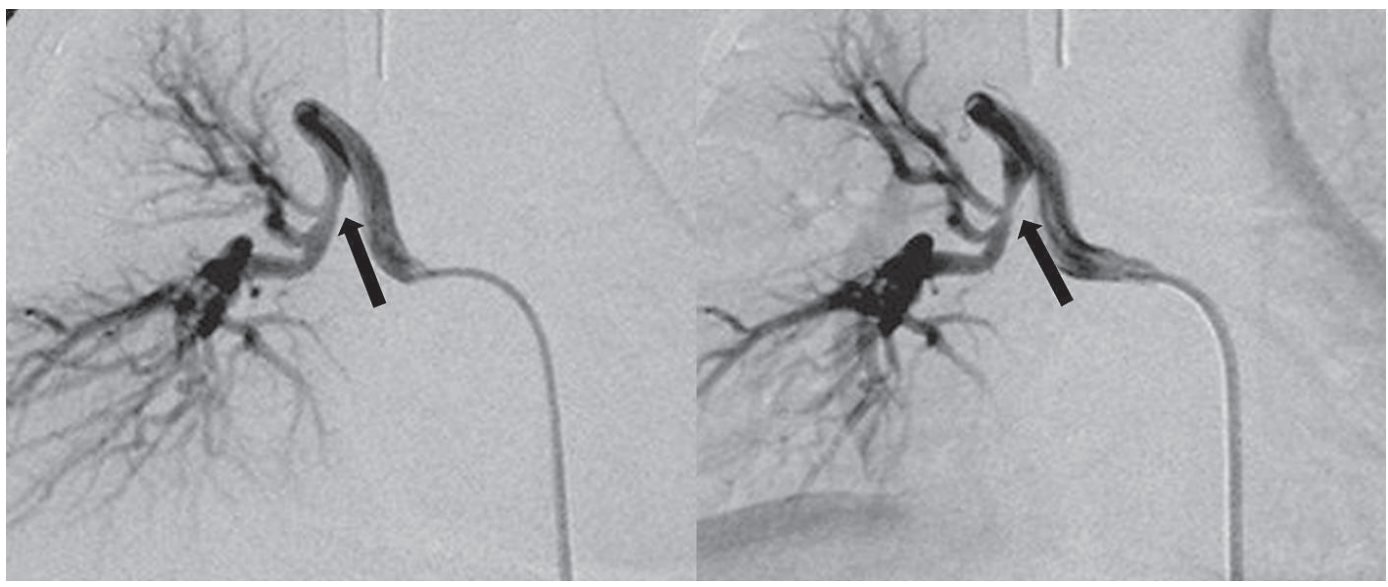

Fig. 4 These figures show an anteroposterior view of DSA in patient 3. Each arrow of the two figures indicates the same portion of the MAPCA. They show MAPCA angiograms without vasospasm in the left and with vasospasm in the right. 


\section{結 論}

死亡症例の大部分を姑息手術後症例が占めており， 死亡原因の半数が突然死であった。死亡を回避した発 作的チアノーゼ増悪患者の検査所見から, MAPCA 攣 縮との関連が疑われた. MAPCA 攣縮が突然死の一因 となっているとも考えられ，発作を起こした症例への 早期の手術介入をすることで, 予後改善につながる可 能性がある。

謝 辞

症例の剖検を担当してくださった千葉県こども病院病理 科の堀江弘先生に深謝いたします。

\section{【参考文 献】}

1) 高尾篤良, 門間和夫, 中澤 誠, ほか: 肺動脈閉鎖兼心 室中隔欠損. 臨床発達心臟病学. 改訂 3 版, 東京, 中外 医学社, 1998, pp.497-502

2) d'Udekem Y, Alphonso N, Nørgaard MA, et al: Pulmonary atresia with ventricular septal defects and major aortopulmonary collateral arteries: unifocalization brings no long-term benefits. Thorac Cardiovasc Surg 2005; 130: 14961502

3) Reinhartz O, Reddy VM, Petrossian E, et al: Unifocalization of major aortopulmonary collaterals in single-ventricle patients. Ann Thorac Surg 2006; 82: 934-938

4) Davies B, Mussa S, Davies P, et al: Unifocalization of major aortopulmonary collateral arteries in pulmonary atresia with ventricular septal defect is essential to achieve excellent outcomes irrespective of native pulmonary artery morphology. J Thorac Cardiovasc Surg 2009; 138: 1269-1275

5) Carotti A, Albanese SB, Filippelli S, et al: Determinants of outcome after surgical treatment of pulmonary atresia with ventricular septal defect and major aortopulmonary collateral arteries. J Thorac Cardiovasc Surg 2010; 140: 1092-1103

6) Hoffman JI: Tetralogy of Fallot with Pulmonary Atresia. The Natural and Unnnatural History of Congenital Heart Disease, Oxford, Wiley-Blackwell, 2009, pp.437-445

7) Leonard H, Derrick G, O'Sullivan J, et al: Natural and unnatural history of pulmonary atresia. Heart 2000; 84: 499503

8) Bertranou EG, Blackstone EH, Hazelrig JB, et al: Life expectancy without surgery in tetralogy of Fallot. Am J Cardiol 1978; 42: 458-466

9) Mainwaring RD, Reddy VM, Reinhartz O, et al: Surgical results in patients with pulmonary atresia-major aortopulmonary collaterals in association with total anomalous pulmonary venous connection. Ann Thorac Surg 2011; 92: 1756-1760

10) Brown SC, Eyskens B, Mertens L, et al: Percutaneous treatment of stenosed major aortopulmonary collaterals with balloon dilatation and stenting: what can be achieved? Heart 1998; 79: 24-28

11) 藤井智子, 下山裕子, 大江克憲, ほか : 麻酔導入後の致 死的低酸素血症が主要大動脈肺動脈側副血行路 (MAPCA)の攣縮によると考えられたPA/VSDの 1 例． 日小览麻酔会誌 2010; 16: 111

12) Watterson KG, Wilkinson JL, Karl TR, et al: Very small pulmonary arteries: central end-to-side shunt. Ann Thorac Surg 1991; 52: 1132-1137

13) Mumtaz MA, Rosenthal G, Qureshi A, et al: Melbourne shunt promotes growth of diminutive central pulmonary arteries in patients with pulmonary atresia, ventricular septal defect, and systemic-to-pulmonary collateral arteries. Ann Thorac Surg 2008; 85: 2079-2083

14) Daliento L, Stritoni P, Chioin R, et al: Systemic-pulmonary arterial supply in pulmonary atresia with ventricular septal defect: postmortem angiograms and histologic survey. Chest 1978; 74: 685-687

15) Thiene G, Frescura C, Bini RM, et al: Histology of pulmonary arterial supply in pulmonary atresia with ventricular septal defect. Circulation 1979; 60: 1066-1074.

16) Anderson RH, Baker EJ, Penny DJ, et al: Pulmonary circulation in the setting of congenitally malformed hearts. Paediatric Cardiology. 3rd Edition, London, Churchill Livingstone, 2009, pp.125-128

17) Reddy VM, Petrossian E, McElhinney DB, et al: One-stage complete unifocalization in infants: when should the ventricular septal defect be closed? J Thorac Cardiovasc Surg. 1997; 113: 858-866 